\title{
Correction or Transfer of Immunodeficiency Due to TNF-LTa Deletion by Bone Marrow Transplantation
}

\author{
Matthias Müller,* Hans-Pietro Eugster,* Michel Le Hir,* \\ Alexander Shakhov, ${ }^{*}$ Franco Di Padova, ${ }^{\dagger}$ Claudine Maurer, ${ }^{\dagger}$ \\ Valerie F. J. Quesniaux, ${ }^{\dagger}$ and Bernhard Ryffel ${ }^{\ddagger}$ \\ *Institute of Toxicology, University of Zürich, Zürich, Switzerland \\ 'Sandoz Pharma, Preclinical Research, Basel, Switzerland \\ ${ }^{\ddagger}$ Institute of Pathology, University of Basel, Basel, Switzerland
}

\begin{abstract}
Background: Mice with inactivated tumor necrosis factor (TNF) and lymphotoxin $\alpha(\mathrm{LT} \alpha)$ genes have profound abnormalities of the immune system including lymphocytosis, lack of lymph nodes, undifferentiated spleen, hypoimmunoglobulinaemia, and defective Ig class switch. Here, we asked whether this phenotype is due to incompetent lymphohemopoietic progenitors or to a defective environment.

Materials and Methods: Lethally irradiated TNF-LT $\alpha-$ deficient and wild-type mice received bone marrow cells from either TNF-LT $\alpha$-deficient or wild-type mice. The reconstitution and transfer of the phenotype was followed by morphological and functional analyses.

Results: Bone marrow cells from wild-type mice restored the synthesis of TNF and LT $\alpha$, corrected the splenic microarchitecture, normalized the lymphocyte counts in the circulation, and repopulated the lamina propria with IgA-producing plasma cells of TNF-LT $\alpha-$
\end{abstract}

deficient mice. Furthermore, the formation of germinal centers in the spleen and the defective Ig class switch in response to a T-cell dependent antigen was corrected, while no lymph nodes were formed. Conversely, the TNF-LT $\alpha$ phenotype could be transferred to wild-type mice by bone marrow transplantation after lethal irradiation.

Conclusions: These data demonstrate that most TNFand LT $\alpha$-producing cells are bone marrow derived and radiosensitive, and that the immunodeficiency due to TNF-LT $\alpha$ deletion can be corrected to a large extent by normal bone marrow cell transplantation. The genotype of the donor bone marrow cells determines the functional and structural phenotype of the TNF-LT $\alpha$-deficient adult murine host, with the exception of lymph node formation. These findings may have therapeutic implications for the restoration of genetically defined immunodeficiencies in humans.

\section{INTRODUCTION}

Tumor necrosis factor (TNF) and lymphotoxin $\alpha$ $(\mathrm{LT} \alpha)$ are mediators of inflammation and immune response $(1,2)$ and are prototypic members of a growing family of TNF-like ligands (37). Both ligands form homotrimers and bind to two different receptors, tumor necrosis factor receptor 1 (TNFR-1) and TNFR-2 (6,8-10). The genetic inactivation of the TNFR-1 $(11,12)$ and

Address correspondence and reprint requests to: Bernhard Ryffel, Institute of Pathology, University of Basel, Schönbeinstrasse, 40, $\mathrm{CH}-4003$ Basel, Switzerland.
TNFR-2 genes (13) gave some indications of the in vivo effects of TNF and LT $\alpha$ mediated through these two receptor systems. Recently a third ligand, LT $\beta$, was identified which is expressed on the cell membrane as a LT $\alpha / 2 \mathrm{LT} \beta$ heterotrimer and binds to the newly described LT $\beta$-specific receptor (LT $\beta-R)(14-16)$, suggesting a novel function for the $\operatorname{LT} \alpha / 2 \operatorname{LT} \beta$ heterotrimer. This pathway likely plays a role in the development of secondary lymphoid organs, since LT $\alpha$-deficient mice lack lymph nodes (17).

We have generated a TNF-LT $\alpha$ doubly deficient mouse, which has a complete disruption of 
the TNF-LT $\alpha$ system, since it has neither the two ligands signaling through the TNFR-1 and -2 nor that signaling through the LT $\beta-\mathrm{R}$ (18). These TNF-LT $\alpha$ doubly deficient mice develop normally with the exception of a profound immunodeficiency. The mutant mice have a 6 -fold increase in circulating B lymphocytes, no peripheral lymphoid organs, an undifferentiated spleen, hypoimmunoglobulinemia, and very few IgA-producing plasma cells in the lamina propria of the small intestine.

Here, we asked whether the complex phenotype of TNF-LT $\alpha$ deficiency is due to incompetent lymphohemopoietic progenitor cells or to a defective environment. For this, we undertook to restore the mutant phenotype by transplantation of wild-type bone marrow cells, and conversely we examined to what extent the mutant phenotype can be transferred by bone marrow transplantation into irradiated wild-type mice.

\section{MATERIALS AND METHODS}

\section{Mice}

TNF-LT $\alpha$ knock-out mice were generated as described on a mixed genetic $129 / \mathrm{Ev} / \mathrm{Sv} \times$ C57BL/6 background (18). Seven- to ten-weekold wild-type and knock-out mice bred in our animal facility and maintained under specific pathogen-free conditions were utilized.

\section{Reagents}

Antibodies used in flow cytometry and FACS analysis were rat anti-mouse monoclonal antibodies (mAb) F4/80, B220, and CD3 (ATTC, Rockville, MD, U.S.A.), MAdCAM-1 (Prof. Holtzmann, München, Germany), CD1lb, ICAM-1, and VCAM-1 (BMA Biomedicals, Augst, Switzerland). Anti-rat globulin goat IgG coupled to Cy-3 (Milan Analytica, LaRoche, Switzerland) or to phycoerythrin (Sigma Chemical Co., St. Louis, MO, U.S.A.) were used as secondary antibody. Biotin-conjugated affinitypurified goat anti-mouse IgM, IgGl, IgG2a, IgG2b, IgG3, and IgA (Southern Biotechnology Associates, Birmingham, AL, U.S.A.), and alkaline phosphatase (AP)-coupled streptavidin (Jackson Immunoresearch Laboratories, West Grove, PA, U.S.A.) were used in ELISA.

\section{Bone Marrow Transplantation}

Recipient mice received a lethal total-body irradiation (determined as 7.0 Gy in the knock-out and wild-type mice), prior to the intravenous injection of $2 \times 10^{6}$ fresh, unseparated bone marrow cells. Blood was collected in EDTAcoated tubes at regular intervals, and the hematological parameters were determined with a Technicon $\mathrm{Hl}$ analyzer.

\section{Injection of Endotoxin}

Mice were injected intraperitoneally with $10 \mu \mathrm{g}$ of LPS (Escherichia coli, serotype O111:B4; Sigma) in saline solution $(0.9 \%)$. Blood was taken $\mathrm{l} \mathrm{hr}$ after LPS injection, and plasma was analyzed for TNF levels. Blood samples were obtained from the tail vein, the retroorbital sinus, or cardiac puncture at euthanasia. Plasma concentrations of TNF were determined by a cytotoxicity assay using the WEHI-164 clone 13 cells (19).

\section{Stimulation of Macrophages and Splenocytes}

Bone marrow-derived macrophages were isolated from femurs and cultivated $\left(10^{6} / \mathrm{ml}\right)$ for 7 days in Dulbecco's minimal essential medium (DMEM) supplemented with $20 \%$ horse serum and $30 \%$ L929 cell-conditioned medium (as source of M-CSF). After 7 days of culture, the cell preparation contains $99 \%$ macrophages (20). The bone marrow-derived macrophages were stimulated with LPS $(10 \mathrm{ng} / \mathrm{ml})$ for $3 \mathrm{hr}$ and the supernatant was assessed for TNF activity as described (19). Freshly isolated splenocytes were stimulated with concanavalin-A $(5 \mu \mathrm{g} / \mathrm{ml})$ for 20 $\mathrm{hr}$. Transcripts for TNF and LT $\alpha$ were determined from total RNA by RT-PCR according to standard protocols (18).

\section{Anti-SRBC Serum Isotype Levels}

Mice were immunized with $2 \times 10^{8}$ SRBC i.v., and serum was collected before and at 3, 6, 9, and 15 days postimmunization. Serum levels of anti-SRBC-specific Ig levels for IgM, IgGl, IgG2a, IgG2b, IgG3, and IgA were determined by a sandwich ELISA. Maxisorp microtiter plates were coated overnight with $50 \mu \mathrm{l}$ of solubilized extract $(3 \mu \mathrm{g} / \mathrm{ml})$ from SRBC prepared according to Kelly (21). Thereafter, plates were blocked with $2 \%$ BSA containing PBS for $2 \mathrm{hr}$ at $37^{\circ} \mathrm{C}$, and serial dilutions of the immune sera were incubated overnight at room temperature. Bound antibodies were detected with biotinylated goat anti-mouse Ig isotype-specific antibodies $(4 \mathrm{hr}$ at room temperature). Subsequently, streptavidin- 
conjugated to alkaline phosphatase and substrate were added for $45 \mathrm{~min}$ each, and the reaction was stopped with $1.5 \mathrm{M} \mathrm{NaOH}$. Absorbance was read at $405 \mathrm{~nm}$ in a Titertek Multiskan spectrophotometer (Flow Laboratories, Allschwil, Switzerland). Serum titers are expressed as the reciprocal value of the dilution showing an optical density of 0.1 over background.

\section{Immunofluorescence Staining of Tissues}

Tissues were snap frozen in supercooled (liquid nitrogen) isopentane and stored at $-80^{\circ} \mathrm{C}$ as previously described (22). Routinely prepared frozen sections were cut at $5 \mu \mathrm{m}$ and fixed in acetone for $10 \mathrm{~min}$, blocked in wash solution $(50$ $\mathrm{mM}$ Tris $/ \mathrm{HCl}, 150 \mathrm{mM} \mathrm{NaCl}$ ) for $30 \mathrm{~min}$, and then incubated overnight at $4^{\circ} \mathrm{C}$ with rat antimouse $\mathrm{mAb}$ specific for CD3, B220, MHC class I and II, F4/80, LFA1, ICAM-1, and MAdCAM-1. Controls, including incubation with secondary antibody alone were uniformly negative. After two washes, sections were incubated with goat anti-rat antibody labeled with Cy-3 at room temperature for $1 \mathrm{hr}$. After a final wash, the slides were mounted in Shandon Immunomount and coverslipped. Immunostained sections were examined with a Laser Scan Microscope 320 (Carl Zeiss, Zürich, Switzerland) in confocal mode with an excitation wavelength of $543 \AA$.

\section{RESULTS}

The Cells Producing TNF Systemically upon Endotoxin Stimulation Are of Bone Marrow Origin

TNF-LT $\alpha$ doubly deficient mice fail to produce TNF after endotoxin injection (18). Upon transplantation with wild-type bone marrow cells TNF-LT $\alpha$-deficient mice respond to endotoxin with TNF plasma levels at $1 \mathrm{hr}$ in the $\mathrm{ng} / \mathrm{ml}$ range similar to wild-type mice (Fig. 1A). TNF-LT $\alpha$ deficient mice lethally irradiated and reconstituted with TNF-LT $\alpha$-deficient bone marrow cells served as controls and behaved essentially as nontransplanted TNF-LT $\alpha$-deficient mice. Conversely, lethally irradiated wild-type mice produced high levels of TNF when reconstituted with wild-type but not with mutant bone marrow cells. These results demonstrate that the majority of cells producing TNF after endotoxin stimulation are radiosensitive and bone marrow derived. Ex vivo, bone marrow-derived macrophages from mutant mice reconstituted with wild-type donor cells produced upon LPS stimu- lation amounts of TNF similar to those from wild-type controls (Fig. 1B).

In addition, after concanavalin-A stimulation splenocytes from mutant mice reconstituted with wild-type bone marrow expressed similar amounts of TNF and LT $\alpha$ mRNA compared with wild-type splenocytes (Fig. 1C). Therefore, TNF and LT $\alpha$ production from both macrophages and $\mathrm{T}$ lymphocytes is restored after reconstitution of TNF-LT $\alpha-$ deficient mice with wild-type bone marrow.

\section{Lymphocytosis in TNF-LT $\alpha$-Deficient Mice Is Not Related to the Absence of Lymph Nodes}

Since TNF-LT $\alpha$-deficient mice have complex immune abnormalities (e.g., increased counts of circulating B lymphocytes, absence of peripheral lymphoid organs, and altered splenic microarchitecture [18]), we asked whether reconstitution of systemic TNF and LT $\alpha$ production by bone marrow transplantation corrects these abnormalities. TNF-LT $\alpha$-deficient mice have a 6-fold increase in lymphocyte counts in circulation compared with wild-type mice $(42.6 \pm 2.3 \times$ $10^{3} / \mu \mathrm{l}$ versus $7.1 \pm 0.4 \times 10^{3} / \mu \mathrm{l} ; n=28$ and 29 , respectively). The high lymphocyte counts of the mutant mice were normalized upon transplantation of wild-type bone marrow. This effect was evident already on Day 42, a time point at which lymphocyte counts of mice reconstituted with TNF-LT $\alpha$-deficient bone marrow had returned to the high control values (Fig. 2). In addition, the effect was long lasting. The normalization was still present 3 months after bone marrow transplantation $\left(11.4 \pm 0.75 \times 10^{3} / \mu \mathrm{l}\right.$ in the mice receiving wild-type marrow versus $36.9 \pm$ $3.8 \times 10^{3} / \mu \mathrm{l}$ in mice receiving mutant marrow; $n=10)$ and was even seen beyond 5 months $\left(8.3 \pm 1.3\right.$ versus $\left.29.3 \pm 4.0 \times 10^{3} / \mu\right)$ in the corresponding groups; $n=3$ ).

Extensive microscopic investigations of the sites where lymph nodes are normally expressed did not reveal any primordial anlage of these structures in TNF-LT $\alpha$-deficient mice (not shown). Transplantation of wild-type bone marrow was unable to restore lymph nodes or Peyers patches (not shown).

By contrast, correction of the TNF-LT $\alpha$ deficiency by wild-type marrow reconstitution restored the regular splenic architecture with the distinct separation of $\mathrm{T}$ and $\mathrm{B}$ cell areas (Fig. 3A), the correct expression of MAdCAM-1 in the marginal sinus and the formation of germinal centers upon antigenic stimulation (not shown). 

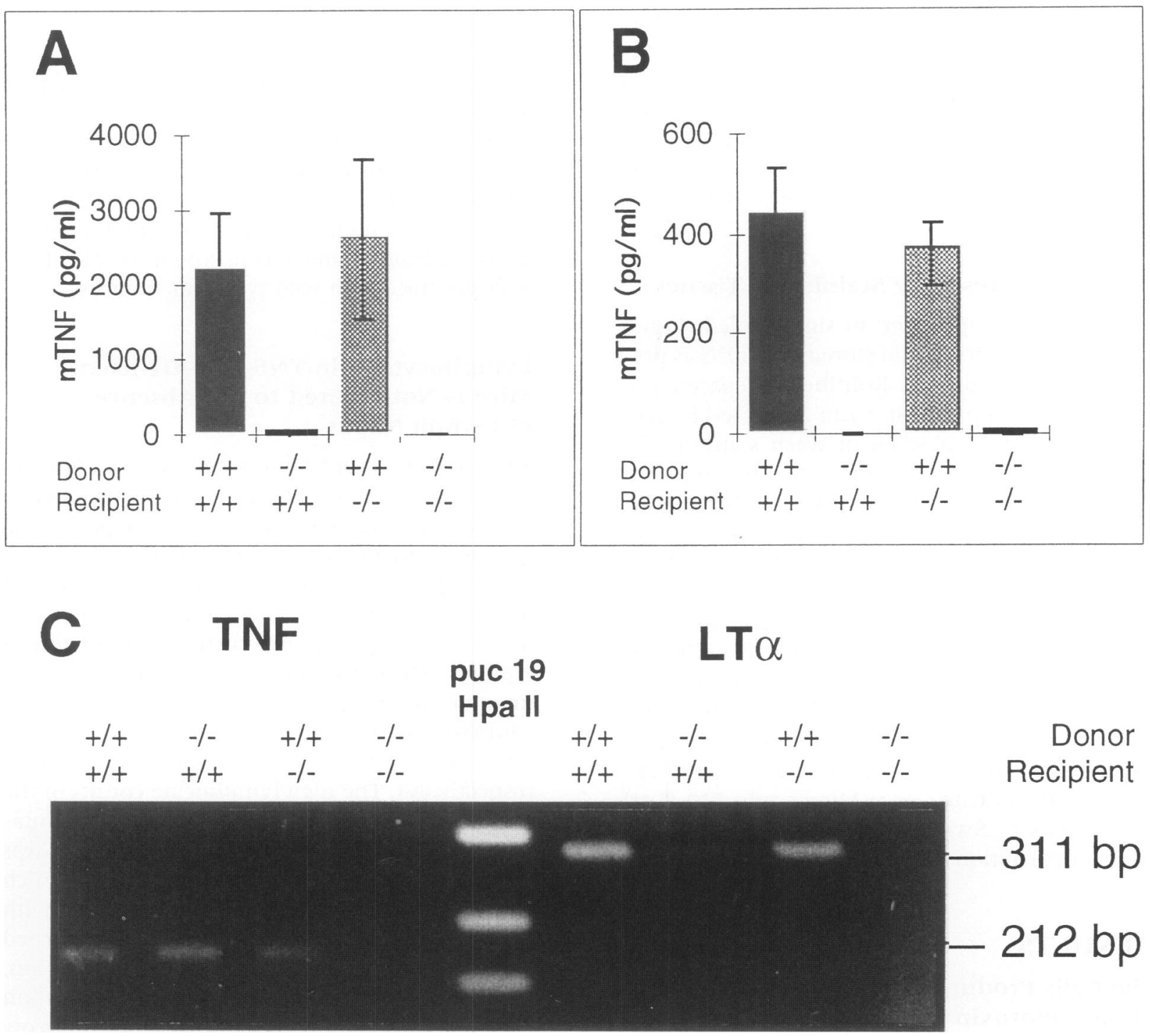

FIG. 1. Correction of TNF and LT $\alpha$ production in TNF-LT $\alpha(-/-)$ deficient mice upon bone marrow transplantation from wild-type mice

(A) TNF plasma levels $1 \mathrm{hr}$ after LPS injection. (B) In vitro TNF production by bone marrow-derived macrophages stimulated with LPS $(3 \mathrm{hr}, 10 \mathrm{ng} / \mathrm{ml})$ in the presence of interferon $\gamma(100 \mathrm{U})$. (C) TNF and LT $\alpha$ mRNA transcription in splenic $\mathrm{T}$ lymphocytes after in vitro concanavalin-A stimulation $(5 \mu \mathrm{g} / \mathrm{ml}$ at $24 \mathrm{hr})$. Bone marrow cells $\left(2 \times 10^{6}\right)$ from wild-type mice $(+/+)$ or from TNF-LT $\alpha$ knock-out $(-/-)$ donor mice were transplanted into lethally irradiated wild-type $(+/+)$ or TNF-LT $\alpha$ knock-out recipient mice $(-/-)$. Analysis of the in vivo TNF production in response to LPS (10 $\mu \mathrm{g}$ i.p.) was performed 47 days post-transplantation, at a time point when the hematological parameters were stabilized (A). In Panels B and C, bone marrow and spleen cells were harvested on Day 84 post-transplantation for in vitro expansion and stimulation. Results are from one representative experiment and are expressed as mean $\pm \operatorname{SEM}(n=3-4)$.

\section{Correction of Defective Immunoglobulin Class Switching in TNF-LTa-Deficient Mice by Wild-Type Bone Marrow Transplantation}

TNF-LT $\alpha$-deficient mice have a profound reduction of IgG and especially of IgA, with an almost complete absence of IgA-producing plasma cells in the lamina propria in the intestine. Upon wildtype marrow cell transplantation, TNF-LT $\alpha$-deficient mice displayed a population of IgA-producing plasma cells in the lamina propria, which was indistinguishable from that of wild-type controls (Fig. 3B).

Abnormalities in the immunoglobulin iso- 


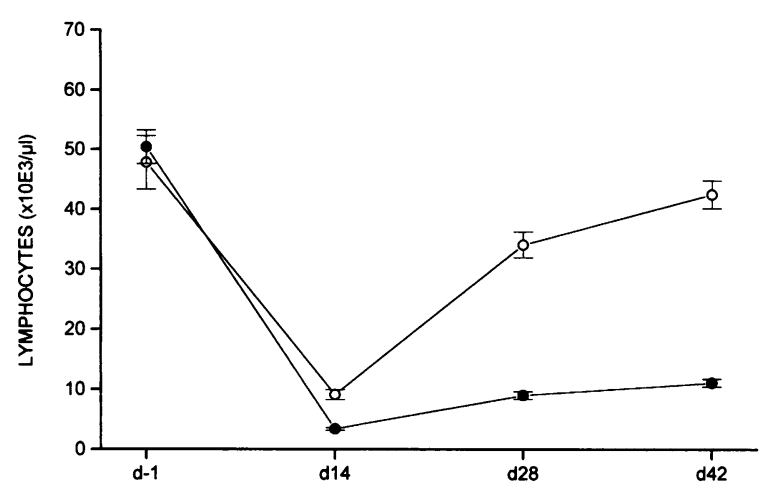

FIG. 2. Peripheral blood lymphocyte counts in TNF-LT $\alpha$-deficient mice after bone marrow transplantation

Wild-type $(\bullet)$ or mutant $(\bigcirc)$ donor bone marrow cells $\left(2 \times 10^{6}\right.$ cells $)$ were transferred into irradiated TNF-LT $\alpha$ knock-out recipient mice as in Fig. 1. Blood was collected in EDTA-coated tubes, and hemograms were determined using a Technicon $\mathrm{Hl}$. The results are pooled from three independent experiments and are expressed as mean \pm SEM ( $n=7-11 \mathrm{mice} /$ group).

type pattern were observed in the serum of naive TNF-LT $\alpha$-deficient mice (18). In addition, they showed impaired Ig class switching in response to the thymus-dependent antigen SRBC. Therefore, we tested whether the Ig class switch was restored after bone marrow transplantation. Upon transplantation of wild-type bone marrow, TNF-LT $\alpha$-deficient mice behaved like the wildtype controls, namely they responded to SRBC injection by a transient synthesis of specific IgM peaking at Day 6 and decreasing at Day 15 (Fig. 4A). At this time point, the IgG response started, as shown for IgG1, IgG2b, and IgG3 (Fig. 4 B-D). This was in contrast to the TNF-LT $\alpha$-deficient mice receiving mutant bone marrow, which showed no IgG responses on Day 15, but persistent IgM titers on Day 15 (Fig. 4 A-D). The block of Ig class switching could be transferred to adult wild-type mice by transplantation of TNF-LT $\alpha-$ deficient bone marrow (Fig. 4 A-D).

\section{DISCUSSION}

The present experiments demonstrate that bone marrow cells are able to reconstitute or transfer the TNF-LT $\alpha$ deficiency when transplanted into adult lethally irradiated recipient mice. Therefore, the genotype of the donor bone marrow cells largely determines the phenotype of the reconstituted host. Furthermore, the data sug- gest that the majority of cells producing TNF and LT $\alpha$ are radiosensitive. Several previous studies indicated that not only monocytes and $\mathrm{T}$ cells, but also many other cell types (e.g., Kupffer cells, hepatocytes, astrocytes, keratinocytes, and renal mesangium and tubular epithelial cells) produce TNF and/or LT $\alpha(1,23,24)$. Kupffer cells are in part bone marrow derived, but are relatively radioresistant (25). Our results suggest that the non-bone marrow-derived cells apparently do not contribute significantly to the systemic release of TNF in response to endotoxin.

While transplantation of wild-type bone marrow could correct the immunodeficiency of adult TNF-LT $\alpha$-deficient mice to a large extent, no lymph nodes were formed. This findings suggest that TNF, or more likely $\mathrm{LT} \alpha$, is required during early development for the formation of lymph nodes. By contrast, the splenic microarchitecture of TNF-LT $\alpha$-deficient mice was completely normalized by bone marrow transplantation. Absence of lymph nodes and a similar alteration of the splenic microarchitecture was reported in LT $\alpha$-deficient mice $(17,26)$, while the TNFR- 1 and -2 had normal splenic structure (1113). Therefore, the correct formation of the spleen appears to be controlled by the LT $\alpha-\beta$ heteromer signaling through the LT $\beta$-R in postnatal development. In addition, the altered splenic microarchitecture seems to be a reversible process, which suggests that LT $\alpha$ expression contributes to splenic differentiation. The data demonstrate that the developmental pathways for lymph nodes and spleen are different.

The increase of peripheral lymphocyte counts seen in TNF-LT $\alpha$-deficient mice was considered to be due to the lack of lymph node structures. However, there seems to be no causal relationship between the two events, our experimental setting having allowed us to separate them. The lymphocyte count was normalized in TNF-LT $\alpha$-deficient mice reconstituted with wildtype bone marrow cells, although no lymph node structures were induced. Conversely, the lymphocyte counts were significantly above normal levels in wild-type mice reconstituted with mutant bone marrow cells $\left(18.6 \pm 1.6 \times 10^{3} / \mu \mathrm{l}\right.$ versus $8.3 \pm 0.8 \times 10^{3} / \mu$ l on Day 42 post-transplantation in three independent experiments; $n=9-10$ mice), although the lymph nodes were present and repopulated (not shown). The lymphocytosis in wild-type mice reconstituted with TNF-LT $\alpha$-deficient bone marrow was stable beyond 3 months $\left(23.5 \pm 1.5 \times 10^{3} / \mu\right.$ l versus 11.2 $\pm 0.7 \times 10^{3} / \mu \mathrm{l}$ in the same experiments; $n=$ 

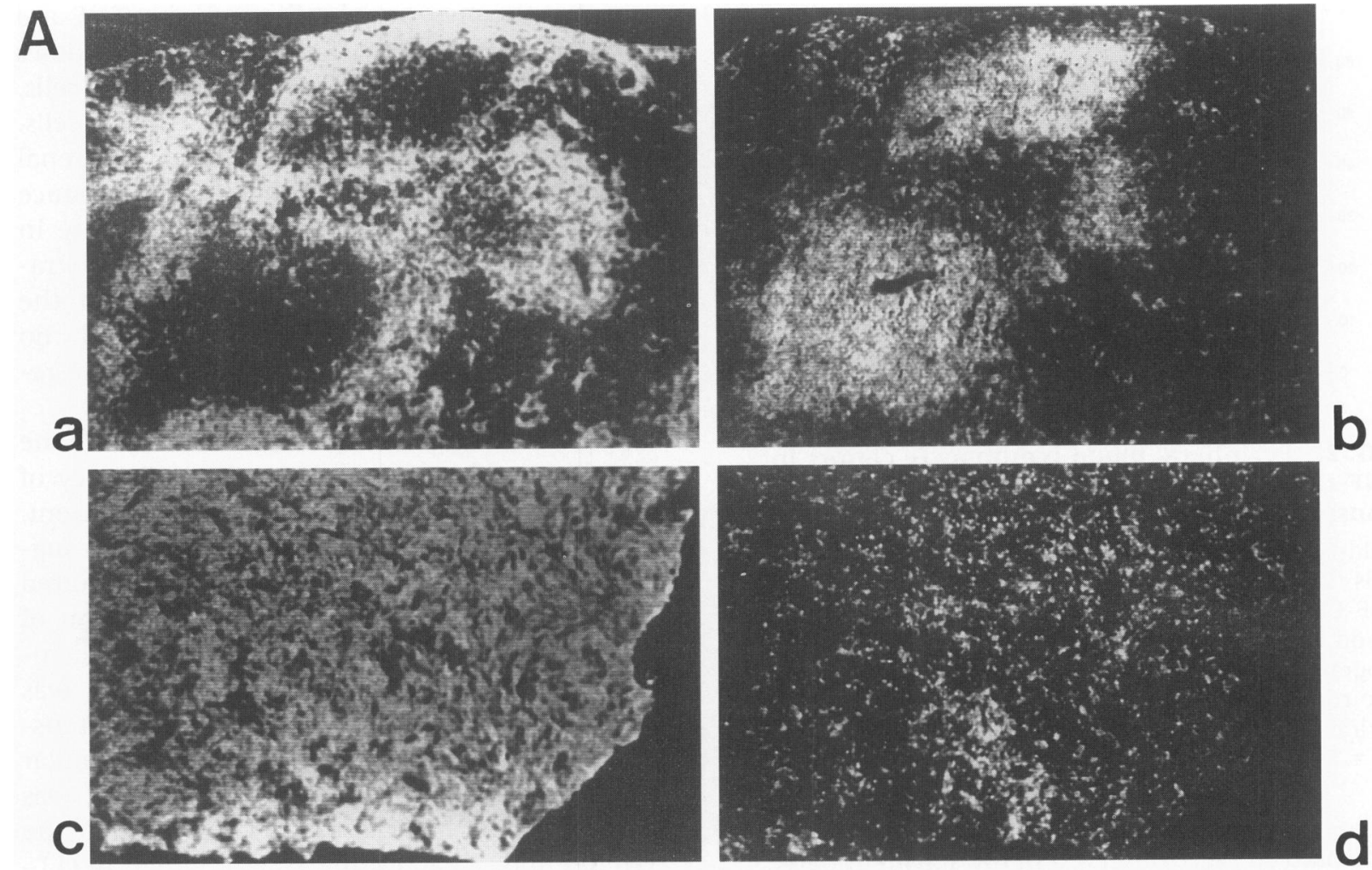



a

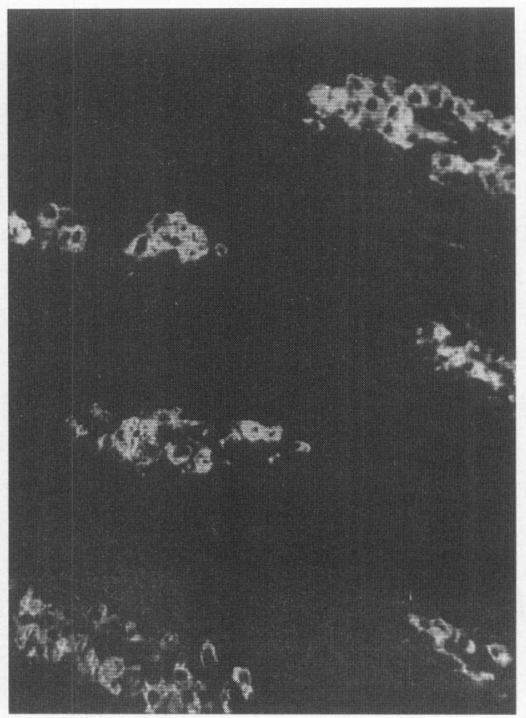

b



C

FIG. 3. Reconstitution of splenic structure (A) and of mucosal IgA-producing plasma cells (B) after wild-type bone marrow transplantation in TNF-LT $\alpha$ knock-out mice

(A) Distinct separation of $\mathrm{T}$ and $\mathrm{B}$ cell areas and germinal center formation after transplantation of wild-type bone marrow cells $\left(2 \times 10^{6}\right.$ cells) into irradiated TNF-LT $\alpha$ knock-out recipient mice. Clearly demarcated B220-positive $B$ cell follicles (a) and CD3-positive $T$ cell areas (b). By contrast, wild-type mice transplanted with mutant bone marrow cells show little distinction between splenic $\mathrm{T}$ and B cell areas, as B220-positive B cells (c) and CD3-positive $\mathrm{T}$ cells (d) are interdispersed. (B) Repopulation of the lamina propria of the ileum with IgA-producing plasma cells. While TNF-LT $\alpha$ knock-out mice have no IgA producing plasma cells in the lamina propria (a), TNF-LT $\alpha$ knock-out mice reconstituted with wild-type bone marrow cells have a repopulation with IgA-producing cells (b) resembling the wild-type control mice (c). 

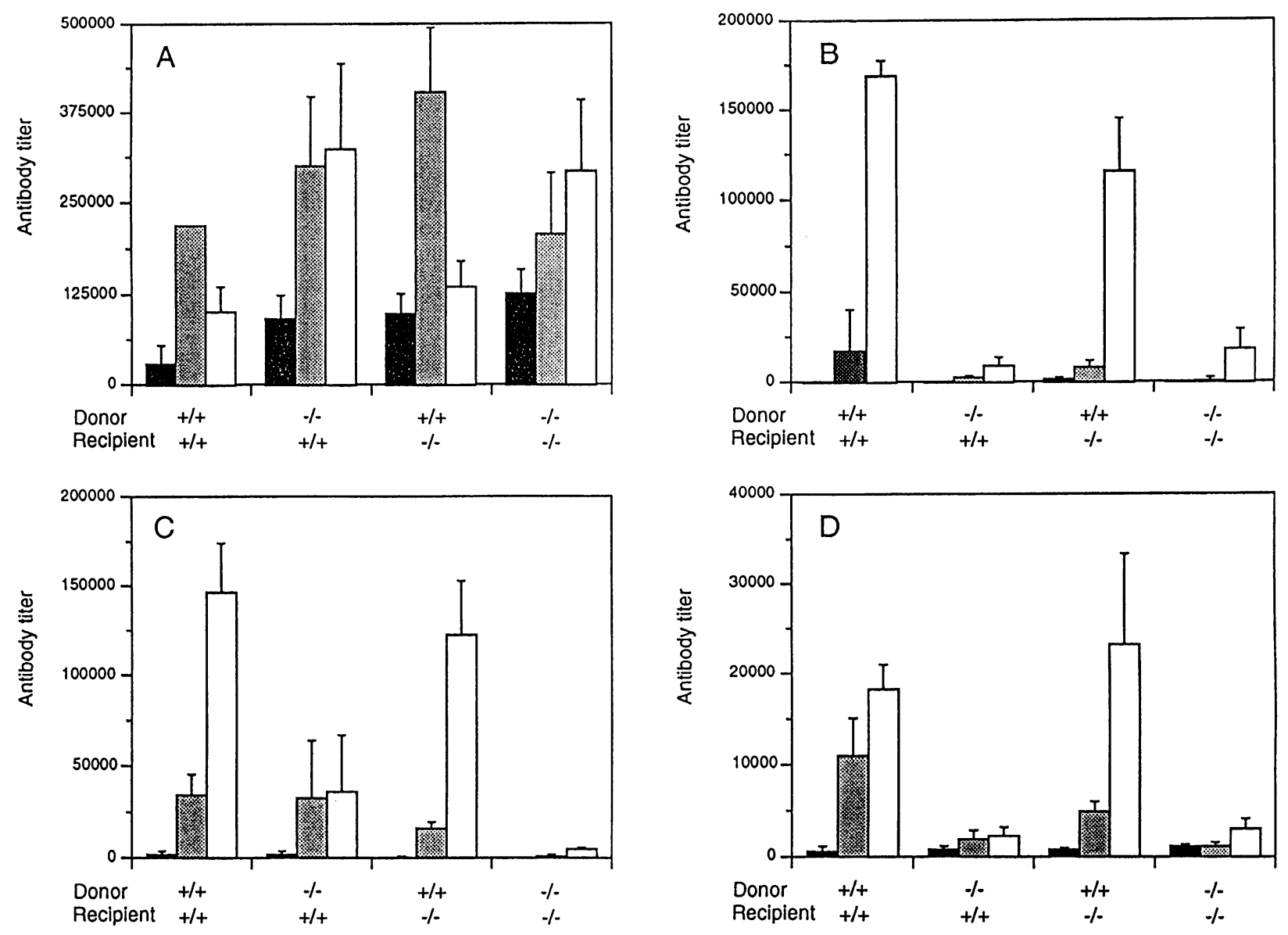

FIG. 4. Restoration of an antigen-induced immunoglobulin class switch upon bone marrow transplantation into TNF-LT $\alpha$-deficient mice

The reconstituted mice were immunized with SRBC $\left(2 \times 10^{8}\right.$ i.p. $)$ and the SRBC-specific IgM (A), IgGl (B), IgG2b (C), and IgG3 (D) titers were determined by ELISA at 6 (shaded bar) and 15 days (open bar) after immunization. Preimmunization sera (black bars) are shown as baseline. Results are pooled from two independent experiments and expressed as mean $\pm \operatorname{SEM}(n=7-8$ mice/group).

10-11) and was still seen beyond 5 months $(21.4$ $\pm 3.5 \times 10^{3} / \mu \mathrm{l}$ versus $10.0 \pm 1.5 \times 10^{3} / \mu \mathrm{l}, n=$ 3-4). It never reached the level of lymphocytosis normally seen in naive TNF-LT $\alpha$-deficient mice $\left(42.6 \pm 2.3 \times 10^{3} / \mu \mathrm{l}, n=28\right)$, a result which would be explained by the minimal residual TNF levels (Fig. 1A) and residual mRNA expression by splenic $T$ cells in these mice (Fig. 1C).

Our results are in agreement with the fact that aly mice, a mutant mouse strain, which are also devoid of lymph nodes, have normal peripheral lymphocyte counts (27). The findings suggest that the peripheral lymphocyte count is not controlled by lymph nodes and, rather, that the TNF-LT $\alpha$-deficient lymphocytes have a homing defect.

Since no defect in the Ig class switch has been observed in TNFR-1-and -2-deficient mice (11-13), we propose that it is the signal from the $\mathrm{LT} \alpha-\beta$ heteromer through the LT $\beta$-R that is necessary for isotype switching. In addition, the data presented here demonstrate that the defective Ig class switch can be corrected by wild-type bone marrow transplantation (e.g., by introduction of TNF-LT $\alpha$-producing cells during adult life of the recipient). The similarities of the immune defect between TNF-LT $\alpha$-deficient and CD40 and CD40 ligand (L) knock-out mice are striking. Indeed, a similar defect of Ig class switch in response to the thymus-dependent antigen, trinitrophenyl-conjugated keyhole limpet hemocyanin (TNP-KLH), was reported for CD40- and CD40L-deficient mice $(28,29)$. This may be of importance since the CD40 ligand is related to 
the TNF family, and CD40 expression in the TNFLT $\alpha$-deficient mice is reduced (data not shown). On the other hand, several reports showed a possible involvement of soluble and membranebound TNF in immunoglobulin production. In particular, soluble TNF is able to enhance the immune response to SRBC (30). It has also been shown that TNF expressed on the membrane of $\mathrm{CD}^{+}{ }^{+} \mathrm{T}$ cells, together with the TNFR 1 , participate in T-B cell interactions resulting in enhanced immunoglobulin production $(31,32)$.

In conclusion, transplantation of normal bone marrow into TNF-LT $\alpha$-mutant mice allowed functional and to some extent morphological correction of the immune defect seen in the TNF-LT $\alpha$-deficient mice. Conversely, the mutant phenotype could be transferred by bone marrow cells transplanted into wild-type recipient mice.

These finding not only provide interesting information on the origin of the cells producing TNF and LT $\alpha$, but may have important therapeutic implications for the restoration of genetically defined immunodeficiencies. Several forms of immunodeficiencies in humans have been described, and the corresponding genetic defects identified. Mutations in the CD40 ligand, a member of the TNF gene family, have been found in $\mathrm{X}$-linked hyper-IgM syndrome (29). While no inactivation of the TNF or LT $\alpha$ genes has been reported so far, there is a substantial polymorphism in human TNF and LT $\alpha$ genes, which is associated with autoimmune disorders. It is very likely that mutations of the TNF and/or LT locus will be identified that are responsible for as yet undiscovered immunodeficiencies in humans.

\section{ACKNOWLEDGMENT}

This work and $M$. Müller were supported by the Swiss National Science Foundation Grant 3233966.92.

\section{REFERENCES}

1. Aggarwal BB, Vilcek J (eds). Tumor Necrosis Factor, Structure, Function, and Mechanism of Action. Marcel Dekker, New York.

2. Beutler B (ed). Tumour Necrosis Factor: the Molecules and Their Emerging Role in Medicine. Raven, New York.

3. Pennica D, Nedwin GE, Hayflick JS, et al. (1984) Human tumour necrosis factor: Pre- cursor structure, expression and homology to lymphotoxin. Nature 312: 724-729.

4. Pennica D, Hayflick JS, Bringman TS, Palladino MA, Goeddel DV. (1985) Cloning and expression in Escherichia coli of the cDNA for murine tumor necrosis factor. Proc. Natl. Acad. Sci. U.S.A. 82: 6060-6064.

5. Goodwin RG, Alderson MR, Smith CA, et al. (1993) Molecular and biological characterization of a ligand for CD27 defines a new family of cytokines with homology to tumor necrosis factor. Cell 73: 447-456.

6. Smith CA, Gruss HJ, Davis T, et al. (1993) CD30 antigen, a marker for Hodgkin's lymphoma, is a receptor whose ligand defines an emerging family of cytokines with homology to TNF. Cell 73: 1349-1360.

7. Suda T, Takahashi T, Golstein P, Nagata S. (1993) Molecular cloning and expression of the fas ligand, a novel member of the tumor necrosis factor family. Cell 75: 1169-1178.

8. Loetscher H, Pan YC, Lahm HW, et al. (1990) Molecular cloning and expression of the human $55 \mathrm{kd}$ tumor necrosis factor receptor. Cell 61: 351-359.

9. Schall TJ, Lewis M, Koller KJ, et al. (1990) Molecular cloning and expression of a receptor for human tumor necrosis factor. Cell 61: 361-370.

10. Beutler B, van Huffel C. (1994) Unraveling function in the TNF ligand and receptor families. Science 264: 667-668.

11. Pfeffer K, Matsuyama T, Kundig TM, et al. (1993) Mice deficient for the $55 \mathrm{kd}$ tumor necrosis factor receptor are resistant to endotoxic shock, yet succumb to L. monocytogenes infection. Cell 73: 457-467.

12. Rothe J, Lesslauer $\mathrm{W}$, Lotscher $\mathrm{H}$, et al. (1993) Mice lacking the tumour necrosis factor receptor 1 are resistant to TNF-mediated toxicity but highly susceptible to infection by Listeria monocytogenes. Nature 364: 798802.

13. Erickson SL, de Sauvage FJ, Kikly K, et al. (1994) Decreased sensitivity to tumour-necrosis factor but normal T-cell development in TNF receptor-2-deficient mice. Nature 372: $560-563$.

14. Androlewicz $\mathrm{MJ}$, Browning JL, Ware CF. (1992) Lymphotoxin is expressed as a heteromeric complex with a distinct $33-\mathrm{kDa}$ glycoprotein on the surface of an activated human T cell hybridoma. J. Biol. Chem. 267: 2542-2547.

15. Crowe PD, VanArsdale TL, Walter BN, et al. 
(1994) A lymphotoxin- $\beta$-specific receptor. Science 264: 707-710.

16. Baens $M$, Chaffanet $M$, Cassiman JJ, vanden-Berghe H, Marynen P. (1993) Construction and evaluation of a hncDNA library of human $12 p$ transcribed sequences derived from a somatic cell hybrid. Genomics 16: 214218.

17. De Togni $\mathrm{P}$, Goellner J, Ruddle $\mathrm{NH}$, et al. (1994) Abnormal development of peripheral lymphoid organs in mice deficient in lymphotoxin. Science 264: 703-707.

18. Eugster HP, Muller M, Karrer U, et al. (1996) Multiple immune abnormalities in tumor necrosis factor and lymphotoxin $\alpha$ double deficient mice. Int. Immunol. 8: 23-26.

19. Espevik T, Nissen-Meyer J. (1986) A highly sensitive cell line, WEHI 164 clone 13 , for measuring cytotoxic factor/tumor necrosis factor from human monocytes. J. Immunol. Methods 95: 99-105.

20. Kelso A, Glasebrook AL, Kanagawa O, Brunner KT. (1982) Production of macrophageactivating factor by $\mathrm{T}$ lymphocyte clones and correlation with other lymphokine activities. J. Immunol. 129: 550-561.

21. Kelly BS, Levy JG, Sikora L. (1979) The use of the enzyme-linked immunosorbent assay (ELISA) for the detection and quantification of specific antibody from cell cultures. Immunology 37: 45-52.

22. Ryffel B, Car BD, Gunn H, Roman D, Hiestand P, Mihatsch MJ. (1994) Interleukin-6 exacerbates glomerulonephritis in (NZB $\times$ NZW)Fl mice. Am. J. Pathol. 144: 927-937.

23. Vassalli P. (1992) The pathophysiology of tumor necrosis factor. Annu. Rev. Immunol. 10: $411-452$.

24. Hunt JS, Chen HL, Hu XL, Chen TL, Morrison DC. (1992) Tumor necrosis factor- $\alpha$ gene expression in the tissues of normal mice. Cytokine 4: 340-346.

Contributed by C. Weissmann on November 27, 1995.
25. Freudenberg N, Freudenberg MA, Hoess CD, Schrecker H, Galanos C. (1986) Investigation into the origin of mouse liver sinusoidal cells. Virchows Arch. A Pathol. Anat. Histopathol. 410: 1-7.

26. Banks TA, Rouse BT, Kerley MK, et al. (1995) Lymphotoxin- $\alpha$-deficient mice: Effects on secondary lymphoid organ development and humoral immune responsiveness. J. Immunol. 155: 1685-1693.

27. Miyawaki S, Nakamura $Y$, Suzuka $H$, et al. (1994) A new mutation, aly, that induces a generalized lack of lymph nodes accompanied by immunodeficiency in mice. Eur. $J$. Immunol. 24: 429-434.

28. Castigli E, Alt FW, Davidson L, et al. (1994) CD40-deficient mice generated by recombination-activating gene-2-deficient blastocyst complementation. Proc. Natl. Acad. Sci. U.S.A. 91: 12135-12139.

29. Renshaw BR, Fanslow WC, Armitage RJ, et al. (1994) Central role of CD40 and its ligand in B lymphocyte responses to T-dependent antigens. J. Exp. Med. 180: 1889-1900.

30. Ghiara P, Boraschi D, Nencioni L, Ghezzi P, Tagliabue A. (1987) Enhancement of in vivo immune response by tumor necrosis factor. J. Immunol. 139: 3676-3679.

31. Aversa G, Punnonen J, de-Vries JE. (1993) The 26-kD transmembrane form of tumor necrosis factor alpha on activated $\mathrm{CD}^{+}{ }^{+} \mathrm{T}$ cell clones provides a costimulatory signal for human B cell activation. J. Exp. Med. 177: 1575-1585.

32. Del-Prete G, De-Carli M, D'Elios MM, et al. (1994) Polyclonal B cell activation induced by herpesvirus saimiri-transformed human $\mathrm{CD} 4+\mathrm{T}$ cell clones. Role for membrane TNF-alpha/TNF-alpha receptors and CD2/ CD58 interactions. J. Immunol. 153: 48724879. 